\title{
Legal problems of the introduction and application of digital technologies in the field of passenger transport
}

\author{
R.B. Bryukhov ${ }^{1}$ and K.E. Kovalenko ${ }^{2 *}$ \\ ${ }^{1}$ Ural State Law University, Yekaterinburg, Russian Federation \\ ${ }^{2}$ Altai State University, Barnaul, Russian Federation
}

\begin{abstract}
Urbanization continues. There is an outflow of population from small cities and towns to large ones. According to some estimates, $60 \%$ of the world's population will live in cities by 2060 (now 50\%). The middle class is growing, and there are more and more people who buy cars. Consequently, the load on urban infrastructure and roads is increasing. The high number of traffic jams leads to negative consequences: the delay in the delivery of goods, the late arrival of people to work, etc. On the other hand, despite the best efforts of manufacturers, transport continues to pollute the atmosphere. Technologies continue to develop rapidly, new business models, rules of doing business in transport and ways to use it are emerging. Recently, there has been the emergence of such innovations as car sharing (the use of cars that are freely available in the city), various types of taxis that can be called up using a mobile phone, and improved urban public transport. In addition, the most current urban trends are the development of pedestrian areas in large cities, non-motorised transport, and bicycles.
\end{abstract}

\section{Introduction}

The strategy of scientific and technological development of Russia marked the exhaustion of the possibilities of the country's economic growth model based on the extensive exploitation of raw materials and the emergence of a limited group of leading countries with new production technologies for the development of digital economy. According to the strategy coming in 10-15 years, the priorities of the scientific and technological development of Russia will be areas that will ensure the transition to advanced digital technologies and robotic systems.

Goals, objectives and measures aimed at the development of the information society, the formation of a national digital economy in the Russian Federation is defined in the Strategy for the Development of the Information Society in the Russian Federation for 2017-2030.

According to the Economic Security Strategy of the Russian Federation until 2030, weak innovation activity, the lag in the development and implementation of new and

\footnotetext{
* Corresponding author: publisher88@mail.ru
} 
promising technologies (including digital economy technologies) are the main challenges and threats to the economic security of the country [1-4].

The need to move to the digital economy is noted in a number of strategic planning documents. The Main Directions of the State Policy on the Development of Competition envisages the improvement of antimonopoly regulation in the context of globalization of digital economy to effectively prevent violations of antitrust laws of a cross-border nature.

The federal program Digital Economy of the Russian Federation based on the markets and technologies of the National Technology Initiative (approved in 2016) and the adopted strategic planning documents (including the forecast of the scientific and technological development of the Russian Federation until 2030).

The need to develop the digital economy is also emphasized internationally. Thus, the member states of the EAEU identified the main directions for the implementation of the digital agenda of the Eurasian Economic Union. According to the Decision of the Supreme Eurasian Economic Council No. 12 of October 10, 2017, digital transformation is assigned to them: sectors of the economy and cross-branch transformation; markets for goods, services, capital and labor; management processes of integration process; development of digital infrastructure and ensuring the security of digital processes [5-8].

Each area defines a part of a single set of issues of cooperation between the member states of these international organizations when discussing initiatives in the development of the digital economy. In the Republic of Tatarstan, an "Integrated System for Monitoring Weight and Dimensional Parameters, Traffic Violations and Fare Applying with RFID Technologies" has been introduced. In the Kaluga region, modern transport solutions are being tested in pilot zones; Digital logistics and smart terminal projects are being implemented on the basis of the multimodal logistics center Freight Village Vorsino.

In the Lipetsk region, an automated cashless payment system for passengers and baggage transportation (ASOP) has been introduced. A unified regional system for the management of road transport and urban ground-based electric transport carrying out regular transportation of passengers and baggage in the Lipetsk region (AIS "Transport Management") was commissioned [9-11].

The implementation of these systems allows obtaining objective information about actually performed transport work, the number of transported passengers (including preferential categories), improving the quality of transport services for the population, optimization of the parameters of the movement of vehicles. Information technologies are being developed in the Tyumen Oblast to improve the distribution infrastructure.

However, it is worth considering the contract for the carriage of passengers and baggage by road in the system of transportation obligations, since this contract is a legal fact that allows passengers to settle the responsibility of the carrier [12-16].

\section{Methods}

The current research uses the methods of observation, comparative legal studies, formal logic, description, and interpretation. If you carefully consider the problem of transport in large cities, you can see the factors that inhibit the introduction of innovations: laws, political issues, land use, the existing structure of cities, consumer habits, etc.

At the same time, many technological aspects help to solve transport problems, as well as new ways of mutual settlements for transportation. For example, in the field of private cars, interesting trends are related to travel without a driver, constant Internet connection, switching to fully safe electric motors, sharing, autonomous driving in general (cars, trucks, trains without drivers) (Table 1). This all leads to optimization of transportation costs, reduction of idle time, accurate implementation of the schedule, reduction in the number of accidents, traffic jams, etc. 
Table 1. Main indicators of work of buses of general use by types of service

\begin{tabular}{|c|c|c|c|c|c|c|c|c|}
\hline & 2000 & 2005 & 2010 & 2011 & 2012 & 2013 & 2014 & 2015 \\
\hline $\begin{array}{l}\text { Number of cities and urban- } \\
\text { type settlements with intercity } \\
\text { traffic }\end{array}$ & 1295 & 1126 & 895 & 1351 & 1666 & 1596 & 1656 & 1621 \\
\hline \multicolumn{9}{|l|}{$\begin{array}{l}\text { The number of routes (at the } \\
\text { end of the year): }\end{array}$} \\
\hline intercity & 6155 & 6104 & 4153 & 3731 & 3391 & 3108 & $\ldots$ & $\ldots$ \\
\hline suburban & $\begin{array}{r}1537 \\
0\end{array}$ & $\begin{array}{r}1494 \\
0\end{array}$ & $\begin{array}{r}1194 \\
7\end{array}$ & $\begin{array}{r}1145 \\
8\end{array}$ & $\begin{array}{r}1141 \\
5\end{array}$ & $\begin{array}{r}1037 \\
4\end{array}$ & $\cdots$ & $\cdots$ \\
\hline urban & 9668 & 8963 & 7289 & 7083 & 6983 & 6746 & $\ldots$ & $\ldots$ \\
\hline \multicolumn{9}{|l|}{$\begin{array}{l}\text { Number of completed trips, } \\
\text { million: }\end{array}$} \\
\hline intercity & 5,9 & 5,5 & 4,2 & 4,0 & 3,5 & 3,2 & 7,7 & 7,4 \\
\hline suburban & 46,8 & 41,0 & 40,4 & 39,7 & 38,4 & 36,7 & 69,4 & 71,9 \\
\hline urban & 172,4 & 132,7 & 126,9 & 126,3 & 124,4 & 124,9 & 304,2 & 311,5 \\
\hline \multicolumn{9}{|l|}{$\begin{array}{l}\text { The share of bus trips made } \\
\text { without delay in the total } \\
\text { number of scheduled trips on } \\
\text { routes, percent: }\end{array}$} \\
\hline intercity & 96 & 98 & 95 & 97 & 96 & 93 & 97 & 97 \\
\hline suburban & 95 & 97 & 97 & 96 & 96 & 96 & 96 & 96 \\
\hline urban & 90 & 92 & 94 & 94 & 92 & 93 & 91 & 92 \\
\hline
\end{tabular}

\section{Results}

The legal status of the land transport environment is connected with the legal status of the state territory on which the transportation is carried out and based on the sovereignty of the state on the territorial entities belonging to it. At the same time, the legal regime of land carriage is subject to the norms of the international law on road traffic management (Convention on Road Traffic of September 19, 1949), customs clearance procedures (Geneva Customs Convention of 1975 on the International Carriage of Goods by TIR Carnet), motorway management (European Agreement, 1975 on international motorways). International road transport of goods is governed by the 1956 Geneva Convention on the Contract for the International Carriage of Goods by Road (CMR), which entered into force on July 2, 1961.

There is a scope of application of the Convention on the Contract for the International Carriage of Goods by Road. The Convention governs the relationship between the carrier and the cargo owner who have entered into a contract for the carriage of cargo, the procedure for receiving cargo for transportation and issuing it at the point of destination.

The Convention applies to any contract for the carriage of goods by means of road transport when the place of loading of cargo and place of delivery of cargo specified in the contract are in two different countries, at least one of which is a party to the Convention, and also if shipments are made by states or government agencies or organizations.

The convention does not apply:

- for carriage performed in accordance with international postal conventions;

- for the carriage of dead;

- for transportation of furniture when moving;

- for shipments between the United Kingdom of Great Britain and Northern Ireland and the Republic of Ireland;

- to the part of multimodal transport that refers to the transport by sea, rail, inland waterway or air transport without overload. 
The contract of carriage is an established invoice. The consignment note is drawn up in three originals signed by the sender and the carrier, and these signatures can be printed by typography or replaced by the sender and carrier stamps if it's allowed by the legislation of the country in which the invoice is made. The first copy of the invoice is sent to the sender, the second - accompanies the goods, and the third - remains with the carrier.

The invoice must contain the following information:

- the place and date of its compilation;

- the name and address of the sender;

- the name and address of the transport agent;

- the place and date of acceptance of the goods for transportation and the place of its delivery, as well as, if necessary, the prohibition of transshipment of the goods;

- the name and address of the recipient;

- designation of the nature of goods and the type of packaging;

- the number of packages, their special layout and numbers;

- the weight of cargo in gross or the amount of cargo expressed in other units of measurement;

- expenses related to transportation: the cost of transportation, additional expenses, if necessary, expenses that the sender receives to his account, customs duties and fees, as well as other costs from the moment of conclusion of the contract until delivery of the cargo;

- instructions required to complete customs formalities;

- an indication that the carriage is carried out independently of any reservation as required by the Convention;

- instructions of the consignor to the carrier regarding insurance of the goods;

- an additional period of transportation;

- list of documents transferred to the carrier.

The consignment note, if not proven contrary, has the force of the contract regarding its conditions and satisfaction with the acceptance of the goods by the carrier. In the absence of reservations substantiated by the carrier in the consignment note, there is a presumption that the goods and their packaging were externally in good condition at the time the goods were accepted by the carrier and that the number of packages, as well as their marking and number, corresponded to the instructions of the consignment note.

The sender is responsible for all costs of transportation and damages caused to him due to inaccuracy or insufficiency of instructions that he must give in the invoice, as well as all other instructions given by the sender for the preparation of the invoice or for inclusion in it. The sender has the right to require the carrier to verify the gross weight or its quantity expressed in other units of measurement. He may also require verification of the contents of packages.

The consignor shall be liable to the carrier for damage caused to persons, equipment and other goods, as well as for any costs that may be caused by damaged packaging of the goods, unless the carrier had done damage to the carrier when it was visible or known to the carrier at the time the goods were accepted.

The sender is obliged to deliver the goods attached to the invoice or provide the carrier with the necessary documents and provide the required information to perform customs and other formalities. The sender is responsible to the carrier for any damage that may be caused by the absence, insufficiency or incorrectness of these documents and information.

The carrier is responsible for:

- for complete or partial loss of cargo;

- for damage to the goods that occurred between the time the goods were accepted for carriage and their delivery;

- for late delivery.

When accepting cargo, the carrier is obliged to check: 
- the accuracy of the entries made in the consignment note regarding the number of packages, as well as their markings and numbers;

- the external state of the goods and their packaging; enter in the invoice reasonable reservations if not received sufficient opportunity to verify the correctness of the records in the invoice.

Upon arrival of the cargo at the place provided for its delivery, the recipient has the right to require the transfer of a second copy of the invoice to him and delivery of the cargo to him on the basis of the relevant receipt.

The right to dispose of the goods is subject to the following conditions:

- the sender or recipient who wants to exercise this right must submit the first copy of the invoice in which the new instructions and data to the carrier must be entered, as well as reimbursement of expenses and damage caused by the implementation of these instructions;

- the implementation of these instructions should be possible at the moment when they are received by the person who is to fulfill them; it must not disrupt the normal operation of the carrier's business and must not cause damage to shippers or recipients of other goods;

- the mentioned instructions should not in any case lead to a breakdown of the goods.

For any disputes arising in connection with traffic carried out in accordance with the Convention, the claimant may apply, in addition to the competent courts of the countries participating in the Convention, which are indicated by common consent of the parties, to the court of the country on whose territory there are:

- the habitual residence of the defendant, its main office, or branch, or agency through which the contract of carriage was concluded;

- the place of acceptance of goods for transportation or place of delivery.

Submission of claims that may arise as a result of traffic may occur within one year. However, in the case of a malicious act or guilt, which, according to the law applied by the court which examines the case, is equal to the malicious act, the period is set at three years. The term is calculated:

- in case of partial loss of cargo, damage to it, or delay in delivery - from the date of delivery;

- in case of loss of the entire cargo - from the 30th day after the expiry of deadline for carriage or, if it has not been established, from the 60th day after the carrier accepts the cargo for transportation;

- in all other cases - upon the expiration of the 3-month period from the date of the conclusion of the contract of carriage.

Types of contracts in the field of international road transport. In the field of international road transport, such groups of contracts are used:

- contracts for the international carriage of passengers and baggage;

- contracts for the international carriage of goods by road;

- agreements on auxiliary operations related to the international carriage of passengers and goods by road.

The contract for the international carriage of passengers and baggage by road is a contract in which one party agrees to the other party to ensure the transportation of passengers and baggage from the point of departure to a destination that is located in different countries.

Passengers are transported by road on the basis of one of the following types of agreements on the international carriage of passengers and luggage:

- foreign economic agreement on joint activities related to the international regular transportation of passengers

- contract on international irregular and commuter road transport of passengers

- agreement on joint activities related to passenger services. 
A foreign economic agreement on joint activities related to the international regular transportation of passengers is an agreement under which the parties to the agreement undertake to jointly act to carry out international regular transportation of passengers for a certain period by buses for a clearly defined number of hours. The parties to the contract are residents and non-residents of the country.

The contract for international irregular and commuter road transport of passengers is any contract in which the carrier provides services to the customer in order to carry out international non-regular and commuter transport of passengers during a certain period of time by buses for a clearly defined number of hours. The parties to the contract on international irregular and pendulum road transport of passengers are the international automobile carrier of passengers and the customer.

The duties of the customer include placing an order for international irregular and commuter carriage of passengers; prior to commencement of transport, a list familiarizing passengers with the conditions for obtaining transport services, informing them in advance about the time and place of the bus and informing about possible additional services; presenting to the head of the group of passengers a list of passengers, as well as route plans and timetables and ensuring their implementation; instructing the leaders of passenger groups on traffic safety issues and passengers on rules of conduct and safety. The customer assists the carrier in controlling over the operation of buses and provides rest and food for drivers.

The carrier's responsibilities include mapping the route and timetables; ensuring timely supply of buses at the agreed time and place on request; ensuring proper technical, sanitary condition of buses and relevant visual information; providing drivers with route schemes and timetables.

The agreement on joint activities related to passenger services is an agreement whereby the parties to the agreement undertake to jointly act in order to provide services to passengers by road at bus stations. The parties to the agreement on joint activities related to passenger services are the carrier and the head of the bus station.

The carrier's duties include ensuring the provision of buses in the proper technical and sanitary condition for boarding of passengers at the bus station, the movement of buses in accordance with the approved timetable, and the arrival of buses in accordance with the timetable for intermediate and terminal stations; ensuring that bus drivers follow the instructions of the bus station manager regarding the organization of the carriage of passengers and baggage and traffic safety.

The duties of the head of the bus station include the organization of proper reception and departure of passengers; the organization of the sale of tickets to the public; ensuring dispatch control and regulation of the movement of buses for the production of equipment and maintenance of buses in proper sanitary condition, compliance with a certain mode of operation of institutions located on the territory of the bus station; organization of consumer services for passengers and drivers.

The contract for the international carriage of goods by road is a contract for the carriage of goods by means of road vehicles when the place of loading and place of delivery of the goods specified in the contract are located in two different countries. According to the contract of carriage of cargo, one party (carrier) undertakes to deliver the cargo entrusted to it by the other party (shipper) to the destination point and give it to the person who has the right to receive the cargo (recipient), and the sender is obliged to pay a fixed fee for the cargo transportation. The parties to the contract for the international carriage of goods by road are the customer and the international road carrier. The customer may be the sender or the recipient of the goods. Both the sender and recipient can be residents or non-residents of the carrier's country. The contract is in favour of a third party - the recipient of the goods, which is located on the territory of a foreign state. Thus, the contract for the international 
carriage of goods by road must comply with the conditions of the foreign economic agreement (contract) and must be concluded in writing. The contract determines the duration of the contract and the conditions of carriage, the cost of carriage and the payment procedure, the procedure for determining rational routes, the rights and obligations of the customer and carrier. The contract regulates the mode of operation for the issuance and reception of cargo, ensuring the protection and preservation of cargo, the implementation of transshipment operations, etc. If transport services of different quality and types are provided, the price is set separately for each service unit, and its total cost is noted as a separate clause of the contract. Allowances, discounts and fines may be provided. The duties of the shipper include the preparation of cargo for transportation before the arrival of the vehicle for loading, taring, sealing, marking, grouping by consignees, as well as timely paperwork for the transportation of cargo; the maintenance of access roads to the points of loading and unloading in a condition that meets the standards of occupational health and safety; provision of equipment and auxiliary materials necessary for loading (unloading); information support in the points of the handling of drivers and other participants in the transport process.

The carrier's responsibilities include determining the type and number of vehicles required for the international carriage of cargo; ensuring timely submission of the vehicle to the load points according to the schedule agreed by the parties; rolling stock must be suitable for the carriage of a particular cargo; ensuring the protection and preservation of cargo from the moment of its acceptance for carriage until the moment of delivery at the point of destination to the consignee. The parties may provide in the contract of road transport additional conditions, which include the insurance definition of loading (unloading) norms, the procedure for paying taxes, customs duties, various kinds of protective clauses, dangerous, perishable and other goods.

Contracts on support operations related to the international road transport of passengers and goods. The contracts that contribute to the international road transport of passengers and goods include the following groups of contracts:

- transport forwarding agreement;

- insurance contracts.

A transport forwarding contract is a materially executed agreement whereby one party (freight forwarder) undertakes to pay for and at the expense of the other party (client) to complete or arrange the fulfillment of services specified in the contract related to international road transport of goods. The freight forwarder is a subject of foreign economic activity, on behalf of the client and at his expense performs or organizes the performance of freight forwarding services as defined by the transport forwarding agreement. A client is a consumer of a forwarder's services - a subject of foreign economic activity who, under a transport forwarding contract, independently or through a representative acting on his behalf, instructs the forwarder to complete or arrange or ensure the fulfillment of the freight forwarding services specified by the contract and pays for them, including the freight forwarder. The client can be both the sender and the recipient of the cargo, which are located in the territories of different states.

The parties to the contract of transport forwarding determine the conditions of transport forwarding by mutual agreement within the norms of international and national law. Thus, these conditions lose their disposition and become imperative. Since the contract of transport forwarding provides for the provision of services related to the organization and provision of transportation of export, import, transit cargo, it is considered as a foreign economic contract and must comply with the requirements of the legislation on foreign economic activity. The external economic contract of transport forwarding is in writing and is legally independent. For the systematic provision of freight forwarding services, longterm (general) transport forwarding contracts may be concluded. 
An insurance contract is one of the types of foreign economic agreements (contracts) between the insurer and the insurer, according to which the insurer undertakes to pay the insured or another person specified in the insurance contract by the insurer in favor of whom the insurance contract has been concluded (provide assistance, perform the service etc.), and the policyholder undertakes to pay insurance payments on time and to fulfill other conditions of the contract.

Insurance contracts are consensual, paid, and bilateral. These treaties are consensual, since only an agreement of the parties is necessary for their conclusion. Insurance contracts are called paid because one party undertakes to make an insurance payment to the other party, provided that the other party undertakes to pay insurance payments. The contract is bilateral, as the two parties to the contract acquire certain rights and become mutually binding. Insurance contracts are in writing. The insurance contract may be concluded by issuing an insurance certificate (policy) by the insurer to the policyholder. The insurance contract comes into force from the moment the insurer makes the first insurance payment, unless otherwise provided by the contract.

There are these types of insurance contracts for international road transport:

- Carrier's liability insurance contract to foreign citizens;

- Carrier's liability insurance contract to passengers;

- Carrier's liability insurance contract to the cargo owner;

- Contract of liability insurance related to customs procedures.

Carrier's liability insurance contract to foreign citizens. When a motor vehicle registered in Ukraine travels to the territory of another country who is a member of the international car insurance system "Green Card", the vehicle owner is obliged to enter into a compulsory third party liability insurance contract for the vehicle owner to third parties, which applies to these countries, and receive from the insurer - a full member of the Motor (Transport) Insurance Bureau - the Green Card insurance certificate of a single sample, which is accepted in all member countries of this international insurance system.

The "Green Card" is issued by a single contract (policy) of the international standard, unlike Ukrainian insurance of civil liability of vehicle owners.

The "Green Card" does not cover the benefits established in Ukraine for certain categories of vehicle owners (drivers) (disabled people affected by the accident at the Chernobyl nuclear power plant, etc.).

The Carrier's liability insurance contract to passengers is a bilateral agreement between the insured (carrier) and the insurer for protection against all existing risks during the period of tourist, shuttle and other passenger and baggage transportation by buses in international traffic. According to the Interbus agreement, in the international carriage of passengers and baggage by buses in international traffic, a "Journal of registration of waybills of passengers" must be drawn up with a list of passengers.

The contract is concluded on the basis of the number of seats: the insurance amount is set for each seat (passenger) in the vehicle and cannot exceed the number of seats provided for by the vehicle manufacturer. The carrier, having paid the insurance payment, receives the insurance certificate valid for the period of validity of the "Passengers checklist register". By issuing an insurance certificate, the carrier guarantees passengers and drivers a system of protection against material losses that may arise as a result of an accident and other risky circumstances during the trip.

Carrier's liability insurance contract to the cargo owner. Several types of insurance contracts may be entered into with respect to the cargo: on the one hand, the resident seller (non-resident buyer) insures the cargo itself; on the other hand, the carrier insures its responsibility to the seller (buyer) for the preservation of this cargo. If an insured event has occurred, then the cargo owner, the carrier, and both insurers are involved in the issue of 
the payment of insurance compensation, as the cargo owner and the carrier may apply to different insurance companies.

In practice, in a foreign economic agreement, the section "Responsibility of the parties" usually provides for the carrier's responsibility to the cargo owner. Therefore, if during transportation the cargo will be damaged or destroyed, the owner draws up a claim against the carrier, and that, in turn, coordinates the issues of compensation for damage with his insurer under the insurance contract of his responsibility.

The contract of insurance of liability of the carrier who transports goods abroad is also called "CMR insurance contract". Such insurance is carried out in accordance with the Convention on the contract for the carriage of goods by road and the norms of the state transport legislation of the country where the cargo is transferred. The carrier insures its responsibility, which may occur as a result of exceeding the delivery time of the cargo, its damage and destruction as a result of various events, for reimbursement of additional expenses.

In some countries, the number of cars is reduced due to the complex trends described above. For example, in the US, the use of personal transport is reduced both by the individual and by the household.

According to the research of world agencies, they can be divided into four large classes:

- stable, old, not very big (Helsinki, Vienna, etc.);

- small with a significant amount of personal transport (many US cities);

-developing - growing large metropolitan areas, where a large influx of population, new housing and new roads are being built (Moscow, Shanghai, cities of Mexico);

- the established megacities - big cities, but already stable (London, New York, Tokyo).

If you look at these "archetypes" of cities, you can see that in general, the number of vehicles per capita is decreasing. At the same time, the use of new technology start-ups ("new mobility") is increasing. The number of movements without a car (pedestrian zones, bicycles) is increasing, cand the development of public transport is taking place.

Thus, all the considered trends are confirmed in almost all classes of cities with small variations (somewhere more, somewhere less), but everywhere - based on information technology.

\section{Conclusions}

Thus, the transportation of passengers and baggage by road, in our opinion, should be defined as the movement of individuals with their belongings by means of vehicles not connected to the power grid, on wheels with their own engine on the roads for the passenger and baggage transportation or chartering a vehicle to transport a passenger and baggage. Determining the contract for the carriage of passengers and baggage by road in the system of obligations for transportation, it can be stated the following.

The contract for the carriage of passengers and baggage by road represents an independent contract in the group of contracts for the carriage of passengers and baggage by vehicles. In this group, it is also possible to identify such types of contracts for the carriage of passengers and baggage, such as transportation by urban ground electric transport, rail, sea and river transport, air transport, tracked transport.

Thus, the definition of the concept of a contract for the carriage of passengers and baggage by road, given within this article, has undisputed theoretical and applied significance. This definition has no official definition enshrined in law. In the literature, as a rule, this type of commitment applies to transportation. Nevertheless, it seems justified to distinguish between motor transport and tram and trolleybus. This theoretical aspect will be fully consistent with the position of the legislator, who shares these types of transport in the name of the Charter of road transport and urban ground electric transport. 
The hybrid model of the new transport is the solution for many problems. In the modern world, this will primarily depend on the development of information technologies, on knowledge of where the transport is, who drove it, where it went, where to fill it, where the electrical outlet for the car is, etc. It seems to me that such management of all transport in real time through information channels will solve the problem of road congestion in big cities.

\section{References}

1. Air Code of The Russian Federation. (1997)

2. Russian Federal Law "On State Regulation of Civil Aviation Development"

3. Russian Federal Law “About financial leasing” (1998)

4. Unidroit Convention on International Financial Leasing (1988)

5. I.A. Reshetnik. Civil-law regulation of leasing in the Russian Federation. (Perm, 1998)

6. M.I. Braginsky, V.V. Vitriansky. Contract law. Book One: General Provisions. (Moscow, 2000)

7. Civil Code Of The Russian Federation. Part Two (1996)

8. K.E. Kovalenko. Some aspects of reasonableness in the law. World Applied Sciences Journal, 7 (2014)

9. A.M. Simonenko, O.N. Troitskaya. Commentary to the Air Code of the Russian Federation (article-by-article). (Moscow, 2007)

10. Order of the Ministry of Transport of the Russian Federation of 02.07.2007 № 85 "On Approval of the Rules for the State Registration of Civil Aircraft of the Russian Federation". Bulletin of Normative Acts of Federal Executive Bodies, 41 (2007)

11. N.V. Vartanyan. On the procedure for state registration of civil aircraft. Transport Law, 3 (2009)

12. Order of the Minister of Defense of the Russian Federation of 28.11.2002 No. 460 "On Approval of Federal Aviation Rules for State Registration of State Aircraft". Bulletin of Normative Acts of Federal Executive Bodies, 20 (2003).

13. Order of the Ministry of Transport of the Russian Federation No. 132 of May 16, 2003 "On Approval of Federal Aviation Regulations" A copy of an aircraft. Requirements and certification procedures "

14. Decree of the Government of the Russian Federation No. 766 of September 12, 2011 "On admission to operation of state aircraft". SZ RF, 38 (2011)

15. M.P. Bardina, B.A. Bulaevsky, N.G. Vilkova. Commentary on the Civil Code of the Russian Federation. (Moscow, 2010).

16. V.D. Bordunov. International Air Law. (Moscow, 2007). 